\title{
OPTIMALISASI PENGHIMPUNAN ZAKAT DIGITAL DI MASA PANDEMI
}

\author{
Annisa Zetira \\ Universitas Indonesia - Kajian Timur Tengah dan Islam \\ annisa.zetira@yahoo.com \\ Nur Fatwa \\ Universitas Indonesia - Kajian Wilayah Eropa \\ nurfatwa@ui.ac.id
}

\begin{tabular}{l}
\hline Article Info \\
\hline Article History: \\
Received 23 August - 2021 \\
Accepted 17 Sept - 2021 \\
Available Online 25 Sept- \\
2021
\end{tabular}

Keyword :

Zakat Collection, Zakat Management, Management Theory of James Stoner

\begin{abstract}
Since the world health organization (WHO) declared Corona Virus Diseases a pandemic, Indonesia's economic growth has weakened. However, zakat collection funds have increased by $30 \%$. This is due to a shift in lifestyle from offline to online to support policies to prevent the spread of the Corona virus. As long as the social restriction policy is enforced, zakat payments cannot be made directly, so zakat management organizations take advantage of this opportunity by innovating in the field of digital technology to strengthen and optimize zakat collection. Even though there is an increase in the number of zakat collections, based on data from Baznas, the acquisition of zakat funds is still very far from the potential zakat figure, so digital zakat management is needed to reach a wider area of socialization, increase the number of muzakki, and increase the number of zakat collections. So that digital zakat collection can run effectively and efficiently, all zakat management organizations (OPZ) that are not yet running optimally need to carry out zakat management by referring to James Stoner's theory that has been carried out by Baznas and other zakat amil institutions. Starting from planning (planning), organizing (organizing), implementation or direction (actuating), and reporting or monitoring (controlling) by utilizing human resources and other resources. This research is a qualitative research and uses a literature review method. The data used is secondary data, which consists of books, journals, reports, zakat outlook, and other literature related to this research. From the secondary data, it was found that Baznas has carried out zakat management effectively, but there are still OPZs that have not done it effectively. One of them is Baznas at the district or city level which experienced a decrease in the number of OPZ in 2019 because it did not have a permit as an official zakat manager.
\end{abstract}

\section{PENDAHULUAN}

Sejak world health organization (WHO) menyatakan Corona Virus Diseases sebagai pandemi pada Maret 2020, World Bank (2020) memprediksi bahwa tidak hanya sektor kesehatan yang terdampak, tetapi juga sektor ekonomi dan sosial di seluruh negara (World Bank 2020). Pertumbuhan ekonomi Indonesia, yang dinyatakan dalam produk domestik bruto
(PDB), mengalami kontraksi ke level -5,3 pada triwulan kedua. Selain itu, melemahnya daya beli, dan berbagai kebijakan terkait pembatasan sosial (social distancing) turut menyebabkan kerugian di sektor ekonomi. Dari sektor sosial, persentase kemiskinan di Indonesia mencapai 9,78\% pada Maret 2020 (BPS 2020) dan meningkat 0,36 poin menjadi $10,14 \%$ pada Maret 2021 (BPS 2021). Oleh karena itu, 
pemerintah membutuhkan sumber dana alternatif untuk memperbaiki pertumbuhan ekonomi. Zakat, sebagai instrumen ekonomi dan keuangan syariah, mampu mengatasi masalah tersebut (Hafidhuddin 2002). Zakat mampu meringankan beban masyarakat yang terdampak covid-19, khususnya pemenuhan kebutuhan dasar masyarakat miskin. Meski demikian, administrasi zakat juga menghadapi tantangan akibat terjadinya kontraksi ekonomi. Angka kemiskinan yang semakin tinggi, dan pemutusan hubungan kerja (PHK) menyebabkan semakin berkurangnya jumlah muzakki (Anshory, Adhiningsih and Saputra 2021).

Di tengah ketidakstabilan ekonomi nasional, pada tahun 2020 Indonesia memperoleh predikat negara paling dermawan di dunia dan berhasil mempertahankan posisi tersebut di tahun 2021 (Charities Aid Foundation 2021). Predikat tersebut dapat diperoleh salah satunya dari angka realisasi pengumpulan zakat yang terus mengalami peningkatan walau di tengah pandemi. Dana zakat yang dihimpun pada tahun 2019 sebesar Rp 10,2 triliun (Puskas Baznas 2021) dan mengalami peningkatan $30 \%$ di tahun 2020 (Anshory, Adhiningsih and Saputra 2021). Namun, pencapaian ini masih belum optimal karena terdapat selisih yang sangat besar dengan angka potensi zakat. Berikut tabel potensi zakat di Indonesia (Puskas Baznas 2021):

\begin{tabular}{|l|l|}
\hline \multicolumn{1}{|c|}{ Sumber Dana Zakat } & \multicolumn{1}{c|}{ Potensi Zakat } \\
\hline Zakat Pertanian & Rp 19,79 triliun \\
\hline Zakat Peternakan & Rp 9,51 triliun \\
\hline Zakat Uang & Rp 58,76 triliun \\
\hline Zakat Penghasilan dan Jasa & Rp 139,07 triliun \\
\hline Zakat Perusahaan & Rp 144,5 triliun \\
\hline Total & Rp 327,6 triliun \\
\hline
\end{tabular}

Sumber: Pusat Kajian Strategik Baznas (2021)

Indonesia sebagai negara dengan jumlah populasi muslim terbesar di dunia (World Population Review 2021), seharusnya mampu mengoptimalkan potensi zakatnya, sehingga sektor ekonomi dan sektor sosial yang terdampak pandemi dapat segera diatasi. Salah satu penyebab belum optimalnya penghimpuan dana zakat adalah karena rendahnya kepercayaan masyarakat terhadap lembaga zakat. Akibatnya masyarakat lebih memilih menyalurkan dana zakatnya langsung ke mustahik (Kashif, Jamal and Rehman 2018), sehingga zakat dapat langsung diterima dan dimanfaatkan. Namun, hal tersebut berdampak pada tidak tercatatnya dana zakat dalam data penghimpunan zakat.

Kedua, tidak adanya regulasi hukum yang memaksa masyarakat muslim untuk membayar zakat (Najiyah and Febriandika 2019). Pengaturan hukum zakat di Indonesia masih sebatas pengaturan pengelolaan zakat dan terkait penguatan kelembagaan (Iqbal 2019). Akibatnya, masih banyak masyarakat Indonesia beranggapan zakat hanya merupakan kegiatan ritual, bukan karena kewajiban sebagai seorang muslim.

Secara umum, akar permasalahan dari kedua masalah tersebut adalah rendahnya tingkat literasi mengenai peran manajemen zakat terhadap kesejahteraan masyarakat dan pertumbuhan perekonomian negara (Mahfud, et al. 2020). Hal tersebut selaras dengan hasil penelitian Istikhomah dan Asrori (Istikhomah and Asrori 2019) yaitu, tingkat literasi masyarakat berpengaruh positif terhadap kepercayaan organisasi pengelola zakat (OPZ). Semakin tinggi kepercayaan muzaki terhadap OPZ, semakin tinggi kepercayaan diri muzaki membayar zakat melalui OPZ, semakin banyak individu yang akan terdorong melakukan hal yang sama (Owoyemi 2020). Oleh karena itu, untuk mengatasi kendala tersebut, dibutuhkan pemanfaatan kemajuan teknologi, informasi, dan komunikasi secara optimal sebagai media edukasi dan berbagi informasi mengenai zakat digital. Terlebih lagi, menurut hasil survey Asosiasi Penyelenggara Jasa Internet Indonesia (APJII) tahun 2019, Indonesia merupakan negara berkembang dengan jumlah pengguna internet dan mobile devices mencapai 196,71 juta jiwa dari total penduduk Indonesia 266,91 juta jiwa. Dengan kata lain, tingkat penetrasi internet di Indonesia mencapai $73,7 \%$, naik 8,9\% dari tahun sebelumnya (APJII 2020). Hal ini merupakan peluang dan tantangan bagi OPZ untuk menyediakan fasilitas jasa keuangan digital agar setiap muslim dapat membayar zakat dengan mudah dan cepat.

Penelitian mengenai manajemen zakat yang mengacu pada teori manajemen James Stoner telah dilakukan sebelumnya. Atabik (2015) menganalisis manajemen pengelolaan zakat yang efektif di era kontemporer dengan model Stoner. Atabik menjelaskan bahwa pengelolaan zakat memerlukan persiapan dan perumusan yang matang agar semua aktivitas pengelolaan dapat dilakukan secara efektif dan efisien. Dengan kata lain, manajemen zakat 
dilihat sebagai suatu fasilitas perantara agar kesempurnaan pelaksanaan zakat dapat tercapai. Pada tahap perencanaan, pengelola zakat pada suatu OPZ dapat melakukan perencanaan sosialisasi ke masyarakat muslim, perencanaan pengumpulan zakat, hingga perencanaan pengawasan zakat yang dapat dengan mudah diakses oleh muzakki, mustahiq, dan stakeholder. Pada tahap pengorganisasian dilakukan dengan melakukan koordinasi dengan sumberdaya manusia dan sumberdaya zakat yang telah dikumpulkan OPZ. Tahap penggerakan dilakukan dengan cara memotivasi SDM OPZ agar memiliki disiplin kerja yang baik. Tahap pengawasan dilakukan untuk memeriksa pengelolaan zakat berjalan sesuai rencana, kemudian melakukan evaluasi untuk perbaikan periode selanjutnya.

Toriquddin dan Rauf (Toriquddin and Rauf 2013) melakukan analisis manajemen zakat menggunakan teori Stoner pada pengelolaan zakat produktif di Yayasan Ash Shahwah (YASA) Malang. Hasil penelitian menunjukkan bahwa YASA telah melaksanakan keempat tahap teori Stoner dengan baik. Pada perencanaan, YASA telah melakukan berbagai program untuk mustahik. Pada pengorganisasian, YASA mempekerjakan banyak staf dan pekerjaan berjalan dengan efektif dan efisien, serta telah memiliki struktur organisasi yang jelas. Pada tahap pelaksanaan, YASA mampu mengelola dana zakat dengan baik, yakni menyalurkannya melalui program beasiswa, program keagamaan atau dakwah, program kesehatan, dan sebagainya. Namun, pengadministrasian muzakki masih belum optimal dengan tidak terdeteksinya jumlah muzakki secara tepat. Pada tahap pengawasan, YASA telah memiliki audit internal dan eksternal walaupun audit eksternal belum berjalan optimal.

Penelitian ini akan fokus menganalisis manajemen penghimpunan zakat di masa pandemi dengan teori manajemen James Stoner pada Baznas, selaku OPZ Pusat. Analisis dilakukan berdasarkan laporan Zakat Outlook. Sehingga, OPZ yang telah melakukan penghimpunan dana zakat dengan efektif, teori Stoner dapat dijadikan acuan untuk memperkuat dan mengoptimalkan penghimpunan zakat digital. Bagi OPZ yang belum melakukannya dengan efektif, teori Stoner dapat digunakan untuk mendorong optimalisasi penghimpunan zakat. Tujuan akhirnya untuk meningkatkan kepercayaan masyarakat terhadap OPZ, sehingga selisih angka realisasi dan angka potensi zakat semakin kecil bahkan ditiadakan.

\section{KAJIAN PUSTAKA DAN PENGEMBANGAN HIPOTESIS} Zakat

Zakat merupakan ibadah yang juga terdapat unsur sosial ekonomi di dalamnya atau dikenal dengan istilah al-ibaadah al-maaliyah al-ijtima'iyyah (Baznas 2016). Unsur sosial ekonomi yang dimaksud adalah zakat berperan sebagai intrumen yang mendistribusikan harta dari ekonomi menengah atas (the wealth) ke golongan ekonomi menengah bawah (the poor) untuk meningkatkan pertumbuhan ekonomi, mengentaskan kemiskinan, dan mereduksi kesenjangan sosial (Widiastuti, et al. 2021). Selain itu, zakat turut berkontribusi membantu sektor pendidikan, usaha mikro dan kecil, kesehatan, dan sebagainya (Saad and Farouk 2019). Agar potensi zakat dapat tercapai, diperlukan persiapan dan perencanaan yang matang, serta dapat dikontrol dan dievaluasi setiap tingkat pencapaiannya. Hal tersebut dilakukan agar pengelolaan zakat dapat berjalan efektif dan efsien. Dengan demikian, agar tujuan zakat dapat tercapai, pengelolaan zakat perlu dikelola dengan baik berdasarkan prinsip-prinsip manajemen. Dari penjelasan tersebut, dapat disimpulkan bahwa manajemen zakat berperan sebagai perantara untuk mencapai pelaksanaan zakat yang optimal.

\section{Teori Manajemen James Stoner}

Ascarya dan Yumanita (Ascarya and Yumanita 2018) menjelaskan definisi manajemen sebagai suatu proses sosial dan teknis memanfaatkan sumberdaya yang ada, mempengaruhi tindakan manusia, dan memberikan fasilitas untuk berubah menjadi lebih baik agar tujuan dapat tercapai. Menurut teori James Stoner dalam Atabik (Atabik 2015), terdapat empat langkah manajemen, yaitu proses perencanaan (planning), pengorganisasian (organizing), pelaksanaan atau pengarahan (actuating), dan pengawasan (controlling) yang dilakukan untuk menentukan dan mencapai tujuan yang telah ditetapkan dengan memanfaatkan sumber daya manusia dan sumber daya lainnya (Afrina 2019). Perencanaan merupakan kegiatan awal dalam sebuah pekerjaan (Hidajat 2017), terdiri dari kegiatan merumuskan rancang bangun organisasi agar mendapatkan hasil yang 
optimal. Pengorganisasian terdiri dari kegiatan koordinasi, penyusunan tugas dan wewenang, penyusunan personalia dan recruitment. Sebuah organisasi akan menjadi kokoh, berkembang, dan maju karena adanya aturan yang jelas dan koordinasi yang baik. Pelaksanaan atau pengarahan merupakan realisasi dari perencanaan organisasi, terdiri dari komunikasi, sosialisasi, model kepemimpinan, pemberian motivasi berupa hadiah dan sanksi. Pelaksanaan didefinisikan juga sebagai proses mempengaruhi orang lain agar mereka mau berusaha mengupayakan yang terbaik, memiliki sikap disiplin, serta memiliki budaya dan etos kerja yang tinggi (Hadi 2020) untuk mencapai tujuan organisasi (Hidajat 2017). Dengan demikian, inti dari proses pengarahan adalah membimbing dan mengawasi karyawan agar bekerja dengan tekun dan tenang agar dapat memahami fungsi dan diferensiasi tugas masing-masing individu dan divisi (Hadi 2020), dan melakukan sosialisasi dengan mengenalkan serta menjelaskan secara rinzi tentang zakat kepada muzakki dan masyarakat umum (Hidajat 2017). Terakhir, pengawasan didefinisikan sabagai proses penjaminan tujuan organisasi dan manajemen tercapai. Proses ini terdiri dari tujuan pengawasan, tipe pengawasan, tahap pengawasan, dan kedudukan pengawas (Hadi 2020).

Keempat model Stoner tersebut dapat diaplikasikan pada setiap aspek manajemen zakat (Atabik 2015), yang terdiri dari aspek penghimpunan, pengelolaan, penyaluran, dan pelaporan (Ascarya and Yumanita 2018). Untuk mengoptimalkan pengelolaan zakat, seluruh aspek manajemen zakat tersebut harus dilakukan sebagai satu kesatuan, bukan secara parsial atau sendiri-sendiri. Al-Qardhawi menjelaskan beberapa syarat yang harus dipenuhi agar manajemen zakat berhasil, khususnya bagi lembaga pengelola zakat, yaitu menetapkan perluasan wajib zakat, mengelola dana zakat secara baik dan transparan, pengelolaan zakat harus tertib administrasi dan dilakukan oleh penanggung jawab yang profesional sehingga dapat dipertanggungjawabkan dengan baik, mendistribusikan zakat kepada mustahik secara akuntabel (Al-Qardhawi 2005).

\section{Penghimpunan Zakat}

Akar permasalahan dari rendahnya pengumpulan dana zakat adalah tingkat literasi masyarakat, maka makalah ini akan fokus memaparkan manajemen zakat pada proses penghimpunan. Penghimpunan merupakan proses memengaruhi masyarakat baik individu maupun lembaga untuk menyalurkan dananya kepada suatu organisasi, baik yang sifanya komersial maupun sosial (Ascarya and Yumanita 2018). Dengan kata lain, penghimpunan dilaksanakan sebagai upaya memperoleh dana zakat dari muzakki (Afrina 2019), sehingga pengumpulan dana zakat, infak, sedekah, dan wakaf yang diperoleh dari masyarakat merupakan peran, fungsi, dan tugas divisi penghimpunan. Oleh karena itu, OPZ membutuhkan amil dengan kemampuan komunikasi yang baik serta kreatif menyusun berbagai macam kegiatan sosialisasi. Penghimpunan dilakukan untuk menumbuhkan kesadaran masyarakat untuk menyalurkan sebagian rezekinya kepada golongan yang membutuhkan (ashnaf), serta menumbuhkan dan meningkatkan kepercayaan masyarakat terhadap OPZ. Salah satu cara untuk mewujudkannya adalah dengan melakukan digitalisasi zakat. Bagi OPZ, pemanfaatan teknologi dapat memudahkan proses penghimpunan hingga pendistribusian sehingga lebih tepat guna dan tepat sasaran. Sedangkan bagi muzakki, teknologi mampu memudahkan penyebaran informasi terkait pentingnya zakat dari berbagai perspektif ilmu, pembayaran zakat, hingga pemantauan proses distribusi dana zakat yang telah diserahkan.

\section{METODE PENELITIAN}

Penelitian ini menggunakan metode kualitatif deskriptif, yaitu penelitian yang menggunakan data kualitatif kemudian dijelaskan secara deskriptif. Metode ini digunakan untuk menganalisis keadaan sosial, suatu kejadian atau fenomena. Jenis penelitian ini adalah studi literatur (literatur review), sehingga data yang digunakan merupakan data sekunder. Literatur yang digunakan terdiri dari buku, jurnal, laporan terkait zakat dari berbagai institusi, dan literatur lainnya yang mendukung penelitian ini. Data sekunder diperoleh dari web site resmi Emerald, Baznas, KNEKS, BPS, dan web site resmi instansi negara lainnya. Fokus penelitian ini adalah menganalisis manajemen penghimpunan zakat digital berdasarkan teori manajemen James Stoner yang telah dilakukan oleh Baznas agar OPZ yang belum melakukan penghimpunan secara optimal dapat memperbaiki manajemen zakat digitalnya. 


\section{HASIL PEMBAHASAN}

Menurut Atabik (2015), terdapat perbedaan pendapat di kalangan ulama tentang tata kelola dan manajemen pengelolaan zakat. Namun, pengelolaan zakat berbasis manajemen adalah kebutuhan bagi masyarakat modern terlebih di era revolusi industri 4.0, dimana berbagai informasi dapat diakses kapanpun dan dimanapun. Hal ini menjadi tantangan bagi OPZ untuk meningkatkan kredibilitasnya, sehingga OPZ dituntut untuk mampu memberikan pelayanan prima, yaitu pelayanan yang tepat, cepat, benar, dan mampu menangani keluhan dengan baik; mampu membuat produk dan program layanan zakat yang kreatif dan inovatif, sehingga kesadaran dan kemauan muzakki untuk memunaikan zakat semakin meningkat (Atabik 2015); mampu mengelola zakat secara profesional serta menyajikan administrasi dan laporan keuangan secara akurat, tepat waktu, transparan, kredibel, dan mudah diakses supaya muzakki tahu kemana dana zakatnya didistribusikan (Hasan 2011); terakhir, OPZ harus mampu mendayagunakan dana zakat dengan baik dan kreatif, sesuai kebutuhan, terukur, dan berkelanjutan agar status mustahik mampu ditingkatkan menjadi muzakki (Mahfud, et al. 2020). Dengan demikian, ekonomi Islam yang maju dan mandiri dapat terealisasi dengan adanya digitalisasi manajemen zakat yang efektif.

Lembaga zakat memiliki tanggung jawab dalam menegakkan maqashid syariah untuk memastikan kesejahteraan manusia, terutama pada masyarakat yang rentan. Selain itu, lembaga zakat juga perlu menjalankan tugas sebagai penghimpun zakat dengan memberikan edukasi dan sosialisasi secara berkelanjutan. Tujuannya meningkatkan kesadaran umat Islam terhadap kewajiban membayar zakat, dampak zakat, dan nilai-nilai yang mendasari pembayaran zakat (Anshory, Adhiningsih and Saputra 2021). Menurut Beik dan Arsyianti (2015), tiga hal utama yang perlu disampaikan kepada publik, yaitu terkait zakat profesi atau zakat penghasilan, zakat perusahaan, dan sumber-sumber zakat modern lainnya; terkait pentingnya membayar zakat melalui Baznas dan LAZ; dan terkait pelajaran atau hikmah dibalik perintah Allah SWT untuk berzakat (Beik and Arsyianti 2015). Berikut empat langkah manajemen berdasarkan model Stoner yang diaplikasikan pada tahap penghimpunan agar sosialisasi berjalan optimal, sehingga kesadaran untuk berzakat dan kepercayaan masyarakat terhadap $\mathrm{OPZ}$ meningkat.

\section{Perencanaan (Planning)}

Menurut Hasan (2011), perencanaan merupakan proses menentukan dan merumuskan semua hal yang dituntut oleh situasi dan kondisi suatu badan usaha atau organisasi. Perencanaan berkaitan dengan upaya yang akan dilaksanakan untuk mengantisipasi hal-hal yang tidak diinginkan dan menentukan strategi yang tepat sasaran dan tepat guna, sehingga target suatu lembaga atau organisasi dapat tercapai. Dalam konteks penghimpunan zakat, perencanaan mencakup pengadaan riset, pencatatan permasalahan yang terjadi, dan perumusan berbagai strategi yang akan dilakukan agar kepercayaan masyarakat terhadap OPZ dapat meningkat.

Berdasarkan nilai indeks kelembagaan, Baznas telah membentuk perencanaan dengan sangat baik, di antaranya SOP pengelolaan zakat, rencana strategi, sertifikasi manajemen mutu (ISO), dan program kerja tahunan (Puskas Baznas 2021). Pembentukan perencanaan secara rinci merupakan hal yang wajib dilakukan oleh seluruh OPZ di Indonesia agar penghimpunan zakat dapat dilakukan dengan optimal. Salah satu rencana yang terus diupayakan dan dikembangkan sejak 2016 adalah digitalisasi zakat. Penyebaran informasi melalui beragam fitur internet diperlukan agar OPZ mampu memberikan edukasi kepada masyarakat dengan jangkauan lebih luas. Di sisi lain, kemudahan memperoleh informasi akan mendorong muzakki memberikan sumbangan dana melalui OPZ (Ascarya and Yumanita 2018).

Puskas Baznas (2021) menyatakan, pengembangan teknologi layanan zakat berbasis teknologi informasi, seperti financial technology, blockchain, dan Internet of Things (IoT) perlu dikembangkan oleh seluruh OPZ. Namun, pemanfaatan teknologi juga menghadapi tantangan salah satunya kesiapan internal OPZ karena akan terjadi revolusi manajemen zakat yang berdampak besar pada internal lembaga, seperti peran amil dan data server zakat. Usman, dkk (2020), menjelaskan bahwa akan terjadi perubahan perilaku dan kebiasaan dalam masa adaptasi teknologi baru, sehingga biasanya masyarakat akan menolak inovasi tersebut. Namun, di sisi lain kebutuhan 
akan teknologi dalam kehidupan sehari-hari semakin meningkat dan masyarakat membutuhkan kualitas layanan yang unggul dan cepat. Lembaga-lembaga zakat dituntut mampu menjawab tantangan tersebut, maka yang dibutuhkan selanjutnya adalah sumber daya manusia yang mumpuni.

\section{Pengorganisasian (Organizing)}

Pengorganisasian

adalah

pengelompokan dan pengaturan sumber daya manusia agar saling bekerja sama sebagai satu kesatuan, sehingga tujuan dan target yang telah ditetapkan dapat tercapai (Hadi 2020). Fungsi perorganisasian berkaitan dengan upaya sebuah lembaga memanfaatkan sumberdaya manusia dan sumber daya materi yang dimiliki secara efektif dan efisien. OPZ perlu menyusun job description masing-masing divisi, kemudian menempatkan sumber daya manusia yang kompetensinya sesuai dengan job description tersebut. Dengan demikian, tahap pengorganisasian merupakan tahap penentuan efektivitas dan efisiensi pengelolaan zakat oleh OPZ.

Baznas, sebagai OPZ pusat, dan OPZ besar lainnya telah memiliki struktur organisasi yang jelas. Masing-masing divisi yang menangani penghimpunan zakat telah memiliki job description yang jelas dan dikerjakan oleh orang-orang yang kompeten. Kerjasama yang baik menghasilkan angka pengumpulan dana zakat meningkat setiap tahunnya, bahkan meningkat signifikan saat terjadi krisis akibat pandemi Covid-19 (Puskas Baznas 2021).

Terdapat dua solusi yang diprioritaskan untuk meningkatkan kompetensi sumber daya manusia di bidang teknologi zakat, yaitu dengan cara intensifikasi dan ekstensifikasi. Intensifikasi dilakukan dengan mengembangkan kemampuan amil dalam menggunakan teknologi, sedangkan ekstensifikasi dilakukan dengan meningkatkan jumlah amil yang mahir di bidang teknologi (Widiastuti, et al. 2021).

\section{Pelaksanaan atau Pengarahan (Actuating)}

Menurut Sudewo (2004) dalam Afrina

(2019), terdapat dua kegiatan penghimpunan zakat, yaitu manajemen penggalangan dana dan layanan donatur. Agar penggalangan atau penghimpunan berjalan efektif dan efisien, perlu dilakukan digitalisasi zakat. Baznas dan sebagian OPZ lainnya bahkan telah memulai digitalisasi beberapa tahun sebelum terjadinya pandemi, sehingga ketika diberlakukan kebijakan pembatasan sosial lembaga zakat hanya perlu menyempurnakan sistem yang ada (Afrina 2019). Ketika OPZ memberikan informasi terkait perencanaan digitalisasi zakat, umumnya masyarakat akan melakukan penolakan kehadiran teknologi baru (Usman, et al. 2020), maka pada tahap pelaksanaan OPZ harus mampu menumbuhkan dan mempertahankan kepercayaan masyarakat dengan menunjukkan integritas (integrity), kemampuan (ability), dan sisi kebajikan (benevolence) kepada muzakki, mustahik, stakeholder, dan masyarakat umum.

Pertama, integritas didefinisikan sebagai kejujuran dalam bertransaksi, artinya kepercayaan dapat tumbuh jika muzakki percaya lembaga zakat tidak melakukan kecurangan pada dana zakat yang dihimpun. Kedua, kemampuan didefinisikan sebagai tingkat kemahiran dan kompetensi amil dalam domain tertentu. Dalam transaksi daring, yang menjadi fokus utama adalah menjaga privasi serta keamanan data. Oleh karena itu, OPZ harus mampu menciptakan sistem keamanan website atau aplikasi yang kuat dan menunjukkan sertifikat keamanan (security certificate) dari lembaga yang kompeten pada halaman website atau aplikasi. Ketiga, sisi kebajikan. Bagi seorang muzakki, zakat tidak hanya sebagai cerminan ketaatan pada ajaran agama, tetapi juga untuk membantu individu lain yang kesulitan memenuhi kebutuhan hidup sehari-hari. Lembaga zakat, sebagai sarana untuk merealisasikan sisi kebajikan muzakki, harus mampu meningkatkan kepercayaan muzakki dan masyarakat dengan selalu berupaya maksimal mewujudkan tujuan tersebut (Usman, et al. 2020).

Digitalisasi zakat nasional dimulai pertama kali pada tahun 2016 saat Baznas bekerja sama dengan Kementerian Agama meluncurkan SiMBA (Sistem Manajemen Informasi Baznas), yang merupakan internal platform penyedia laporan keuangan tahunan Baznas. Peluncuran SiMBA dilakukan dua tahun lebih awal dibanding peluncuran Road Map Indonesia 4.0 oleh Menteri Perindustrian yang menjadi titik awal masuknya Indonesia ke era digital 4.0. Hingga saat ini OPZ di Indonesia telah menggunakan tiga digital platform, yaitu internal platform yang dikembangkan oleh lembaga itu sendiri, di antaranya web site dan aplikasi resmi masing-masing lembaga; external platform yang merupakan bentuk 
kerjasama OPZ dan partner untuk meningkatkan penghimpunan zakat, di antaranya commercial platforms, social media platform, innovative platform, artificial intelligence platform; dan crowdfunding platform seperti kitabisa.com (Puskas Baznas, 2020 dan Ninglasari \& Muhammad, 2021).

Saat ini Indonesia berada di peringkat keempat sebagai negara pengguna internet terbanyak di dunia (World Population Review 2021), dimana masyarakat dapat dengan mudah mengakses informasi terkait zakat. Dengan tersedianya data kinerja penghimpunan zakat, berupa prestasi kerja dan laporan tahunan (annual report) yang transparan dan akuntabel, kepercayaan masyarakat untuk menyalurkan dana zakatnya melalui OPZ dapat meningkat. Sehingga OPZ mampu meningkatkan jumlah muzaki, menambah penerimaan zakat, mengurangi risiko, dan meningkatkan kesejahteraan mustahik (Basrowi and Utami 2020) walau dalam keterbatasan di masa pandemi.

Kegiatan penghimpunan zakat yang kedua adalah layanan donatur. Dengan adanya layanan donatur atau muzakki, mereka akan merasa diperhatikan dan dilibatkan di setiap aspek manajemen zakat. Pencatatan nama donatur menjadi salah satu strategi krusial penghimpunan agar silaturahim antara muzakki, amil, dan mustahik tetap terjaga (Afrina 2019). Dalam merumuskan kebijakan pengumpulan dana zakat, lembaga amil zakat perlu mempertimbangkan kendala dan ekspektasi muzakki supaya kepercayaan muzakki terhadap OPZ semakin meningkat. OPZ, sebagai organisasi penyedia layanan pengumpulan zakat, perlu terus meningkatkan kualitas layanan mengikuti perkembangan zaman guna memberikan kemudahan bagi muzaki dan calon muzaki (Antonio, Laela and Ghifari 2020). Menurut Kinanti, dkk (2021), terdapat empat strategi yang dapat dilakukan OPZ dalam menghimpun zakat secara digital, yaitu optimalisasi kanal media sosial, memberikan kemudahan layanan dan dalam waktu bersamaan melakukan edukasi pentingnya berzakat kepada muzaki, memperluas portofolio program yang berdampak langsung pada mustahik, dan mendistribusikan zakat secara transparan dan akuntabel (Kinanti, et al. 2021).

\section{Pelaporan atau Pengawasan (Controlling)}

Pengawasan adalah mencari tahu dan memeriksa apakah hal-hal yang dikerjakan sesuai dengan ketentuan dan peraturan yang berlaku, kemudian memberikan solusi yang tepat jika terjadi kendala dan kesalahan. Proses pengawasan harus dilakukan secara berkelanjutan guna meminimalkan tingkat kesalahan kerja. Selain itu, pada proses ini juga dilakukan evaluasi terhadap keberhasilan pencapaian target apakah sudah sesuai dengan ketentuan yang berlaku (Hasan 2011). Tujuan dari pengawasan adalah agar dapat segera dilakukan klarifikasi dan koreksi jika terjadi penyimpangan, sehingga solusi dapat segera ditemukan dan organisasi dapat kembali beroperasi sesuai dengan ketentuan yang berlaku.

Untuk mengawasi proses penghimpunan zakat, dapat dilakukan pengukuran menggunakan Indeks Zakat Nasional dengan pembobotan minor. Pembobotan minor merupakan penilaian dari sisi internal OPZ, yakni kelembagaan dan dampak zakat yang diberikan. Pembobotan minor terdiri dari variabel penghimpunan atau pengumpulan, pengelolaan, penyaluran, pelaporan, indeks kesejahteraan CIBEST, modifikasi IPM, dan kemandirian. Adapun pembobotan mayor yang dilakukan untuk menilai faktor-faktor eksternal yang mempengaruhi OPZ, seperti dukungan pemerintah dan database. Pembobotan mayor terdiri dari variabel regulasi daerah, dukungan APBN untuk BAZNAS, jumlah lembaga zakat resmi, muzaki, dan mustahik, rasio jumlah muzaki individu terhadap rumah tangga di tingkat nasional, dan rasio jumlah muzaki badan usaha terhadap jumlah badan usaha di tingkat nasional.

Selain IZN, terdapat Indeks Kepatuhan Syariah Organisasi Pengelola Zakat (IKSOPZ) yang disusun oleh Baznas sebagai upaya pengawasan manajemen zakat. IZN disusun pada tahun 2016 dan merupakan alat ukur kinerja pengelolaan zakat yang pertama diluncurkan. Pengukuran IZN dilakukan secara komprehensif baik dari sisi internal dan eksternal. Pada tahun 2020, Baznas meluncurkan IKSOPZ yang merupakan alat ukur untuk mengidentifikasi tingkat kepatuhan lembaga zakat tehadap hukum-hukum Syariah dan peraturan yang berlaku di Indonesia. Alat ukur tersebut dikembangkan oleh Pusat Kajian Strategis (Puskas) Baznas dan Kementerian 
Agama RI (Puskas Baznas 2021). Dalam aspek penghimpunan, aktivitas pengawasan turut dilakukan dalam bentuk pendampingan berupa pembinaan pengembangan, penyelesaian masalah yang dialami oleh OPZ, hingga peningkatan mental spiritual karyawan OPZ (Hidajat 2017).

\section{KESIMPULAN}

Keempat model manajemen James Stoner, yaitu proses perencanaan (planning), pengorganisasian (organizing), pelaksanaan atau pengarahan (actuating), dan pelaporan atau pengawasan (controlling), dapat diaplikasikan pada setiap aspek manajemen zakat, yang terdiri dari aspek penghimpunan, pengelolaan, penyaluran, dan pelaporan. Dalam aspek penghimpunan, Pada aspek penghimpunan, perencanaan yang akan dilakukan adalah melakukan sosialisasi zakat serta penghimpunan dana zakat melalui berbagai lini sosial media agar dapat menjangkau seluruh wilayah Indonesia. Tahap berikutnya, pengorganisasian, dibutuhkan koordinasi antar divisi untuk mewujudkan rencana yang telah ditetapkan. Selain itu dibutuhkan juga intensifikasi dan ekstensifikasi agar amil zakat mampu beradaptasi dengan cepat pada setiap perubahan dan perkembangan, terutama di bidang teknologi finansial. Kemudian, pada tahap pelaksanaan, meskipun telah dilakukan digitalisasi zakat melalui internal platform, external platform, dan crowdfunding platform, OPZ terus berupaya mengembangkan jaringan digital untuk menjangkau lebih banyak muzakki, menghimpun dana zakat lebih banyak karena selisih realisasi dan potensi zakat masih sangat besar. Terakhir, tahap pelaporan atau pengawasan telah dilakukan menggunakan Indeks Zakat Nasional (IZN) dan Indeks Kepatuhan Syariah Organisasi Pengelola Zakat (IKSOPZ) yang disusun oleh Baznas. Selain itu, pada aspek penghimpunan, aktivitas pengawasan turut dilakukan dalam bentuk pendampingan berupa pembinaan pengembangan, penyelesaian masalah yang dialami oleh OPZ, hingga peningkatan mental spiritual karyawan OPZ.

\section{REFERENSI}

Afrina, Dita. 2019. "Manajemen Zakat di Indonesia sebagai Pemberdayaan Ekonomi Umat." EkBis: Jurnal Ekonomi dan Bisnis 2 (2): 201-212.
Al-Qardhawi, Yusuf. 2005. Spektrum Zakat dalam Membangun Ekonomi Kerakyatan. Jakarta: Zikrul Media Intelektual.

Anshory, Ali Hamani Al, Siti Maulida Adhiningsih, dan Muhammad Indra Saputra. 2021. "Strategy of Zakat Colletion during COVID-19 Pandemic: Muzakki Perception." Baznas Center of Strategic Studies 1-12.

Antonio, M S, S F Laela, dan D M A Ghifari. 2020. "Optimizing Zakat Collection in the Digital Era: Muzakki's Perception." Jurnal Dinamika Akuntansi dan Bisnis 7(2), 235-254.

APJII. 2020. Laporan Survey Internet APJII 2019-2020 (Q2). Jakarta: Asosiasi Penyelenggara Jasa Internet Indonesia.

Ascarya, dan Diana Yumanita. 2018. "Analisis Rendahnya Pengumpulan Zakat di Indonesia dan Alternatif Solusinya." Working Paper Bank Indonesia 1-95.

Atabik, Ahmad. 2015. "Manajemen Pengelolaan Zakat yang Efektif di Era Kontemporer." ZISWAF, Jurnal Zakat dan Wakaf 2 (1), 40-62.

Basrowi, dan Pertiwi Utami. 2020. "Pemanfaatan Teknologi dalam Peningkatan Penerimaan Zakat, Jumlah Muzaki, dan Pengurangan Resiko Zakat." Al-Urban: Jurnal Ekonomi Syariah dan Filantropi Islam 4(1), 101-114.

Baznas. 2016. Outlook Zakat Nasional 2016. Jakarta: Badan Amil Zakat Nasional.

Beik, Irfan Syauqi, dan Laily Dwi Arsyianti. 2015. "Optimization of Zakat Instrument in Indonesia's Poverty Alleviation Programe." Poverty Alleviation and Islamic Economics and Finance: Current Issues and Future Prospect. Durham: Research Gate. 120.

BPS. 2020. Persentase Penduduk Miskin Maret 2020 Naik Menjadi 9,78 Persen. 15 July. https://www.bps.go.id.

-. 2021. Persentase Penduduk Miskin Maret 2021 Turun Menjadi 10,14 Persen. 15 July. https://www.bps.go.id.

Charities Aid Foundation. 2021. CAF World Giving Index 2021: A Global Pandemic Special Report. London: Charitied Aid Foundation.

Hadi, R. 2020. "Manajemen Zakat, Infaq, dan Shadaqah di Badan Amil Zakat 
Nasional (BAZNAS) Kabupaten Banyumas." El-Jiyza: Jurnal Ekonomi Islam 8(2): 245-266.

Hafidhuddin, Didin. 2002. Zakat dalam Perekonomian Modern. Jakarta: Gema Insani.

Hasan, Muhammad. 2011. Manajemen Zakat Model Pengelolaan yang Efektif. Yogyakarta: Idea Press.

Hidajat, Rahmat. 2017. "Penerapan Manajemen Zakat Produktif dalam Meningkatkan Ekonomi Umat di PKPU (Pos Keadilan Peduli Umat) Kota Makassar." Millah: Jurnal Studi Agama 63-84.

Iqbal, Muhammad. 2019. "Hukum Zakat dalam Perspektif Hukum Nasional." Jurnal Asy-Syukriyyah, 20(1) 26-51.

Istikhomah, D, dan Asrori. 2019. "Pengaruh Literasi terhadap Kepercayaan Muzaki pada Lembaga Pengelola Zakat dengan Akuntabilitas dan Transparansi sebagai Variabel Intervening." Economic Education Analysis Journal 8(1), 95109.

Kashif, M, K Faisal Jamal, dan M Abdur Rehman. 2018. "The Dynamics of Zakat Donation Experience among Muslims: A Phenomenological Inquiry." Journal of Islamic Accounting and Business Research, 9(1) 45-58.

Kinanti, R A, S Imani, M Hasanah, dan K Asyaria. 2021. "Optimalisasi Fundrising Zakat pada Kerjasama Institusional Indonesia Melalui ECommerce Pasca Pandemi Covid-19.” Jurnal Manajemen Zakat dan Wakaf 2(1), 20-37.

KNEKS. 2019. Sharia Economy: Boosting Financial Inclusion through Sharia Economy in Indonesia. Jakarta: Komite Nasional Ekonomi dan Keuangan Syariah.

Mahfud, Choirul, R F Tsalatin, L Amelia, N S Dewi, M I Fatchurozi, M R Ibenzani, dan F Agung. 2020. "Digitalization of Islamic Philanthropy: Effectiveness of Management of Zakat and Waqf in Contemporary Indonesia." Studia Religia: Jurnal Pemikiran dan Pendidikan Islam 4 (2): 203-214.

Najiyah, Faridatun, dan Nur Rizqi Febriandika. 2019. "The Role of Government in the Zakat Management: the Implementation of a Centralized and
Decentralized Approach (Comparative Study in Indonesia and Malaysia)." 1st International Conference on Islamic Economics and Business (ICONIES 2018). The Netherlands: Atlantis Press. 290-292.

Owoyemi, M Y. 2020. "The Crisis of Confidence in Zakat Agencies and the Legality of Giving Zakat Directly to the Poor." Journal of Islamic Accounting and Business Research 498-510.

Puskas Baznas. 2020. Outlook Zakat Indonesia. Jakarta: Pusat Kajian Strategis Baznas.

Puskas Baznas. 2021. Outlook Zakat Indonesia 2021. Jakarta: Pusat Kajian Strategis Badan Amil Zakat Nasional.

Saad, R A J, dan A U Farouk. 2019. “A Comprehensive Review of Barriers to a Functional Zakat System in Nigeria: What Needs to be Done?" International Journal of Ethics and Systems 35(1): 24-42.

Santoso, Ivan Rahmat. 2019. "Strategy for Optimizing Zakat Digitalization in Alleviation Poverty in the Era of Industrial Revolution 4.0.” IKONOMIKA: Jurnal Ekonomi dan Bisnis Islam 4 (1): 35-52.

Usman, Hardius, Dipa Mulia, Chairy, dan Nucke Widowati. 2020. "Integrating Trust, Religiosity, and Image into Technology Acceptance Model: the Case of the Islamic Philanthropy in Indonesia." Journal of Islamic Marketing 1-29.

Widiastuti, Tika, Eko Fajar Cahyono, Siti Zulaikha, Imron Mawardi, dan Muhammad Ubaidillah Al Mustofa. 2021. "Optimizing Zakat Governance in East Java Using Analytical Network Process (ANP): The Role of Zakat Technology (ZakaTech)." Journal if Islamic Accounting and Business Research 12(3): 301-319.

World Bank. 2020. Poverty and Distributional Impacts of Covid 19: Potential Channels of Impact and Mitigating Policies. $16 \quad$ April. https://www.worldbank.org.

World Population Review. 2021. Internet Users by Country 2021. 1 January. https://worldpopulationreview.com.

—. 2021. Muslim Population by Country 2021. $1 \quad$ january. https://worldpopulationreview.com. 
Zubaidah, Siti, dan Afifah. 2020.

"Development of Zakat Management

Digitalization in Indonesia." 4th

International COnference of Zakat
(ICONZ). Surabaya: Proceedings. 459468. 